\title{
GETTING STARTED WITH MAC
}

\section{Jan LAVRINČÍK, Petr ŠKUTA \\ PRVNÍ KROKY S MACEM ZAČÍNÁME S MACEM}

JANEČEK, V. První kroky s Macem. 1. vyd. Dražovice : Jitka Janečková, 2011. 124 s. ISBN 978-80904816-0-2.

JANEČEK, V. Začínáme s Macem. 2. vyd. Dražovice : Jitka Janečková, 2011. 124 s. ISBN 978-80904816-1-9.

O knihy zaměřené na moderní informační a komunikační technologie není u nás nouze. Kvalitních publikací zaměřených na alternativní platformy Apple, Linux, Android je stále nedostatek. V roce 2011 vyšlo v malém nakladatelství Jitky Janečkové aktualizované vydání knihy První kroky s Macem zaměřené na poslední verzi operačního systému Apple OS X Lion. První verze knihy zaměřená na starší verzi systému Mac OS X Snow Leopard vyšla v roce 2010 pod názvem Začínáme s Macem.
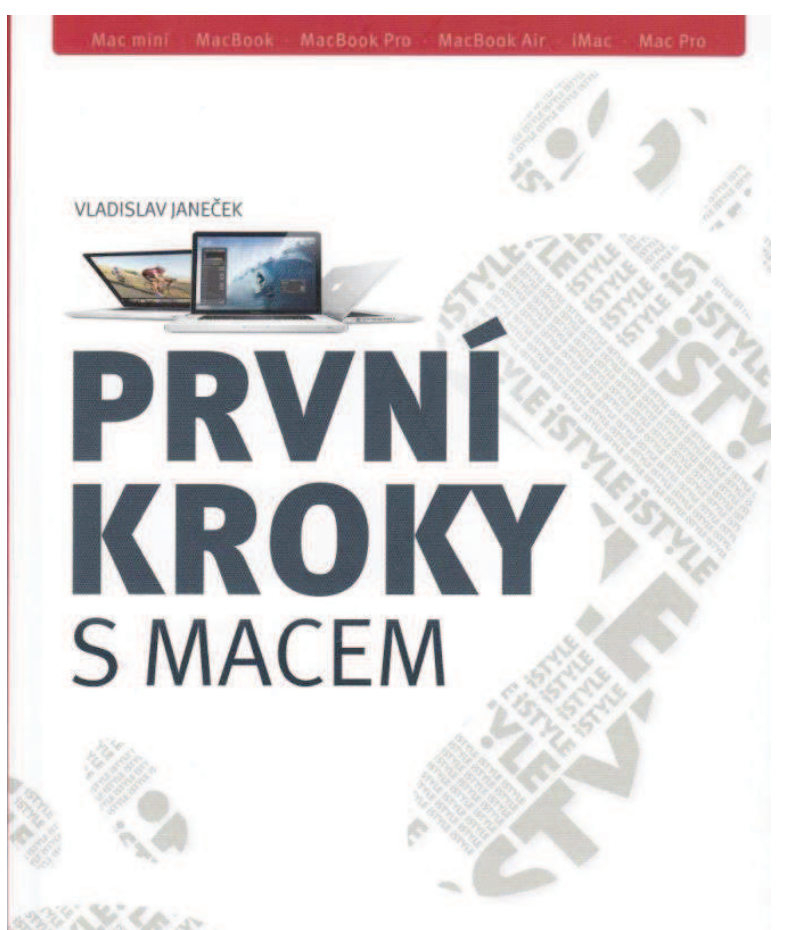

\section{iSTYLE}

Autor knihy Vladislav Janeček je známý „nadšenec“ a uživatel platformy Apple, prošel několika významnými tuzemskými redakcemi tišstěných i webových časopisů zaměřených na IT. V současné době vydává své články ve vlastních elektronických magazínech www.superapple.cz a www.superiphone.cz. V roce 2011 začal vydávat časopis orientovaný pouze na platformu Apple s názvem SuperApple magazín dostupný v České republice a na Slovensku. Mimo výše uvedeného profesní zaměření se autor knihy věnuje profesionálnímu zpracování videa.

Kniha s názvem „První kroky s Macem“ je rozdělena do jedenácti kratších kapitol. Nám se dostala $\mathrm{k}$ recenzování jak speciální edice určená $\mathrm{k}$ distribuci s novými počítači Apple od Premium Resseler iStyle, ale také klasická verze určená pro knihkupectví a širokou distribuci. Prvně jmenovaná se od běžné edice se liší na pohled obalem s logem společnosti iStyle. Krom tohoto si lze ještě povšimnout dvoubarevné úpravy tisku - modrošedé. Jinak bychom však hledali rozdíly marně, ve zbylém jsou knihy téměř totožné. Nadále se tedy soustředíme na veřejně dostupnou verzi.

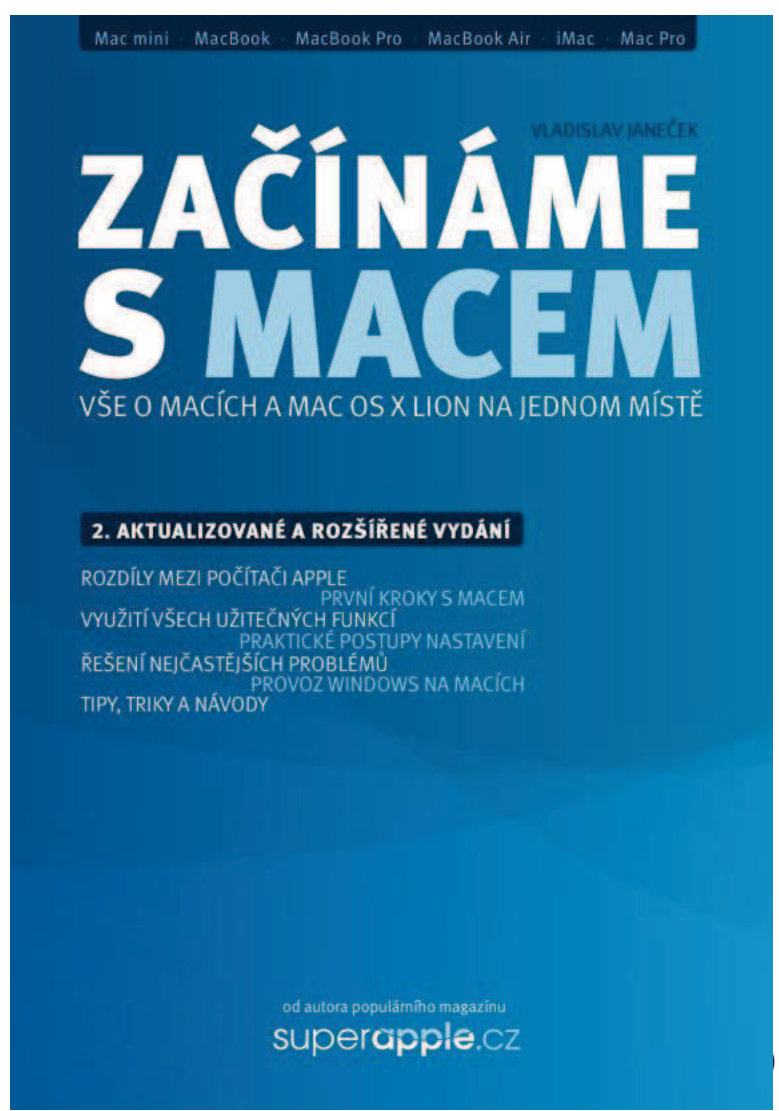


Kniha začíná představením platformy Apple, stolních počítačů, notebooků a jejich rozdílů od klasických počítačů. Např́klad v jedné z podkapitol najdeme komplexní informace o obdobě touchpadu - takzvaném trackpadu nebo magnetickém napájecím konektoru MagSave.

Začínáme s Macem je nejen název knihy, ale i druhé kapitoly. Kapitola přináší cenné poznatky zejména pro začínající uživatele, protože se snaží uživatelům OS Windows poradit, jak zvládnout rutinní záležitosti: prostředí systému, spuštění aplikací, zavírání aplikací, Dock, řádek nabídek, odinstalování aplikací a specifika klávesnice Macu.

Třetí kapitola nás učí, jak manipulovat s daty v jiném operačním systému, hledat soubory pomocí inovativního nástroje Spotlight, používat bleskově rychlý náhled, listovat $\mathrm{v}$ dokumentech $\mathrm{v}$ režimu náhledu dokumentů apod.

V pořadí čtvrtá kapitola se zabývá prácí s texty. Práci s dokumenty můžeme zařadit $\mathrm{k}$ jedněm $\mathrm{z}$ nejčastějších činností na počítači. Autor nás zde mimo jiné seznamuje se všemi kancelářskými balíčky, kde největší pozornost věnuje kancelářskému balíčku Microsoft Mac Office 2011. Jako ekvivalent předkládá iWork z dílny Apple a freeware Libre Office. Samostatná podkapitola je věnovaná nastavení českého slovníku. Apple OS Lion je první verzí, která ve standardu obsahuje českou lokalizaci, ale kancelářské balíčky Microsoft Office zatím lokalizovány nejsou.

Pátá kapitola o práci v síti řeší klíčové otázky sítí LAN a Wi-Fi a to zejména $\mathrm{z}$ pohledu kompatibility se standardními komunikačními protokoly známými z Microsoft Windows. $\mathrm{V}$ podkapitolách je názorně vyobrazen postup připojení sít'ových tiskáren a disků.

Samostatná šestá kapitola poodhaluje práci s internetem. Operační systémy Apple v základu obsahují webový prohlížeč Safari, jehož ovládání může být zpočátku pro uživatele jiných operačních systémů specifické. V úvodu kapitoly nechybí informace o prohlížečích třetích stran (Opera, Mozilla Firefox, Google Chrome).

Elektronická pošta byla podrobně zpracována v sedmé kapitole. Úvod kapitoly patř́i už tradičně alternativám vestavěného emailového klienta. Ve standardní instalaci OS X systémů je integrována aplikace Mail sloužící primárně k odesílání a př́ijímání pošty. Samostatnou kapitolu si pošta vysloužila i díky spojení se službou iCloud a podpoře účtů poskytovatelů trretích stran Gmail i korporátního Microsoft Exchange.
V pořadí osmá kapitola o zálohování je rozdělena na dvě části. První uživatele učí, jak udělat přesnou kopii systému za pomoci aplikace Carbon Copy Cloner. Ve druhé obsáhlejší části předkládá podrobný návod na použivání a nastavení aplikace Apple TimeMachine.

Usnadněte si práci a život popisuje tematicky rozmanitá kapitola. Obsah bychom mohli vystihnout slovy tipy a triky se systémem OS X. Jak organizovat práci s okny, vypalovat CD/DVD disky, udělat snímek obrazovky nebo doinstalovat kodeky zjistíme v deváté kapitole.

Předposlední kapitola iCloud představuje sadu přelomových služeb sloužící $\mathrm{k}$ práci $\mathrm{s}$ obsahem a jeho vzájemnou synchronizací mezi nejen Apple zařízeními $v$ rámci sítě internet. K synchronizaci všech služeb bude nutné vytvořit Apple ID, které je mimo služby iTunes, App Store nezbytné mít na přihlášení $\mathrm{k}$ iCloud. Pečlivě popsaný proces vytvoření najdeme včetně názorných obrázků. Dále se zde nachází návod, jak službu využívat na operačním systému OS X, ale i na ostatních systémech pomocí libovolného webového rozhraní.

Úplně poslední kapitola se nese v duchu instalace a virtualizace systému MS Windows na platformě OS X. Zprvu jsou krátce představeny všechny dostupné aplikace. Podrobněji autor věnuje pozornost standardnímu nástroji BootCamp, který nabízí provoz systému v tzv. př́mém běhu. $Z$ nástrojů pro virtualizaci je zde představen Virtual Box, hlavně kvůli distribuci zcela zdarma.

Kniha působí přepychovým dojmem, díky křídovému papíru použitému nejen na přebal, ale i všechny stránky. Kniha, tak může plnit funkci stylového manuálu k počítači s operačním systémem OS X. Design je velmi jednoduchý a uhlazený, jak jej známe z produktů společnosti Apple.

V celé knize postrádáme kapitolu zaměřenou na práci s grafikou. Náhradu aplikace malování, jak je to s aplikacemi Adobe Photoshop, Autodesk AutoCAD. Platforma Mac se těší zájmu obzvláště u uměleckých profesí (práce s grafikou, videem apod.) a proto si myslíme, že podobnou kapitolu by si kniha zasloužila. To jsou snad jediné maličkosti, které můžeme knize vytknout. Oproti prvnímu vydání došlo ke sjednocení stylu obrázků i úvodníků kapitol a poznámek. V knize pomocí těchto úprav mnohem lépe orientuje.

Knihu bychom mohli doporučit zejména těm, kteří chtějí přejít $\mathrm{z}$ platformy Windows na platformu Mac. Dále učitelům s inovativním 
přístupem $\mathrm{k}$ alternativním platformám ve vzdělávání. V současné době díky vydání bezplatné aplikace iBooks Author si myslíme, že by si platforma Mac mohla najít své nezastupitelné místo $\mathrm{v}$ českém školství a učitelům se hodit jako rychlá príručka.

PhDr. Jan Lavrinčík, DiS.

Katedra technické a informační výchovy Pedagogická fakulta UP

Žižkovo nám. 5,

771 40, Olomouc,

\& Ústav informatiky,
Moravská vysoká škola Olomouc

Jeremenkova 1142/42

Tel.: +420 585635813

E-mail: nobilis.felis@seznam.cz

Www pracoviště: www.mvso.cz

Petr Škuta

Katedra technické a informační výchovy

Pedagogická fakulta UP

Žižkovo nám. 5,

771 40, Olomouc,

E-mail: me@petrskuta.com

Www pracoviště: www.kteiv.upol.cz 